\title{
Bromus tectorum Response to Fire Varies with Climate Conditions
}

\author{
Authors: Kimberley Taylor, Tyler Brummer, Lisa J. Rew, \\ Matt Lavin, and Bruce D. Maxwell
}

The final publication is available at Springer via http://dx.doi.org/10.1007/s10021-014-9771-7 in Ecosystems.

Taylor, Kimberley, Tyler Brummer, Lisa J. Rew, Matt Lavin, and Bruce D. Maxwell. "Bromus tectorum Response to Fire Varies with Climate Conditions." Ecosystems 17 no. 6 (2014): 960-973. http://dx.doi.org/10.1007/s10021-014-9771-7

Made available through Montana State University's ScholarWorks scholarworks. montana.edu 


\title{
Bromus tectorum Response to Fire Varies with Climate Conditions
}

\author{
Kimberley Taylor, Tyler Brummer, Lisa J. Rew, and Bruce D. Maxwell: Land Resources and \\ Environmental Sciences Department, Montana State University, Bozeman, Montana \\ Matt Lavin: Plant Sciences and Plant Pathology Department, Montana State University, Bozeman, \\ Montana 59717, USA \\ Tyler Brummer: Bio-Protection Research Centre, Lincoln University, Lincoln, Canterbury, New \\ Zealand
}

\begin{abstract}
Author contributions: Kimberley Taylor conceived of/designed study; performed research; analyzed data; and wrote paper. Tyler Brummer performed research and wrote paper. Lisa J. Rew conceived of/designed study and wrote paper. Matt Lavin contributed new methods/models and wrote paper. Bruce D. Maxwell conceived of/designed study; performed research; and wrote paper.
\end{abstract}

\begin{abstract}
The invasive annual grass Bromus tectorum (cheatgrass) forms a positive feedback with fire in some areas of western North America's sagebrush biome by increasing fire frequency and size, which then increases B. tectorum abundance post-fire and dramatically alters ecosystem structure and processes. However, this positive response to fire is not consistent across the sagebrush steppe. Here, we ask whether different climate conditions across the sagebrush biome can explain B. tectorum's variable response to fire. We found that climate variables differed significantly between 18 sites where $B$. tectorum does and does not respond positively to fire. A positive response was most likely in areas with higher annual temperatures and lower summer precipitation. We then chose a climatically intermediate site, with intact sage-brush vegetation, to evaluate whether a positive feedback had formed between $B$. tectorum and fire. A chronosequence of recent fires (1-15 years) at the site created a natural replicated experiment to assess abundance of $B$. tectorum and native plants. $B$. tectorum cover did not differ between burned and unburned plots but native grass cover was higher in recently burned plots. Therefore, we found no evidence for a positive feedback be-tween B. tectorum and fire at the study site. Our results suggest that formation of a positive B. tectorum-fire feedback depends on climate; how-ever, other drivers such as disturbance and native plant cover are likely to further influence local responses of B. tectorum. The dependence of B. tectorum's response to fire on climate suggests that climate change may expand B. tectorum's role as a transformative invasive species within the sage-brush biome.
\end{abstract}

\section{INTRODUCTION}

Invasive plant species can cause distinct and longlasting changes to community structure and function (Levine and others 2003). A fundamental shift in ecosystem function can occur where invasive plant species alter fire regimes resulting in negative consequences for native communities (Brooks and others 2004). Bromus tectorum (cheatgrass), an invasive annual grass, is often cited as a quintessential example of a species that has ecosystem level impacts by altering the pre-invasion fire regime 
in the western USA sagebrush biome (Pellant 1990; D'Antonio and Vitousek 1992; Brooks and others 2004; Mack 2011). B. tectorum senesces early in the summer and increases fine fuel load and continuity, which can lead to more frequent and larger fires (Whisenant 1990; Link and others 2006; Balch and others 2013). Many studies have found an increase in B. tectorum abundance, biomass or seed production following fire, particularly in the Great Basin and south-central Washington (West and Hassan 1985; Billings 1994; Chambers and others 2007; Davies and others 2009, 2012a), creating a positive feedback between fire and B. tectorum. This feedback has resulted in dense stands of $B$. tectorum in many areas of the western USA (Mack 2011). Some have suggested that fire in certain sagebrush steppe and grassland communities can result in a transition to an annual-dominated alternative state (Young and Evans 1973; Davies and others 2009, 2012a; Mack 2011). However, others have found that the response of $B$. tectorum to fire is ephemeral (Christensen 1964; Hosten and West 1994; West and Yorks 2002; Mata-Gonzalez and others 2007). Furthermore, in the eastern or northeastern part of the sagebrush biome (parts of Idaho, Wyoming and Montana) studies have found no response of $B$. tectorum to fire (Blaisdell 1953; Antos and others 1983; Humphrey 1984; Cook and others 1994; Seefeldt and McCoy 2003; Menke and Muir 2004). In addition, $B$. tectorum invasion or transitions to $B$. tectorum-dominated vegetation states can occur without fire (Bangert and Huntly 2010; Bagchi and others 2013).

Clearly ecosystem level impacts due to $B$. tectorum invasion after fire are strong in some regions, such as many parts of the Great Basin, but nonexistent in others. There are several alternative hypotheses to explain B. tectorum's differential response to fire across its invaded range in the western USA. Prior disturbance, such as grazing or previous fires, has been suggested as a potential driver; however, grazing has been an inconsistent predictor of postfire invasion (Seefeldt and McCoy 2003; Davies and others 2009, 2012a; Rew and Johnson 2010). Fire severity has also been implicated as a mechanism that can alter $B$. tectorum response to fire with higher $B$. tectorum abundance in more severely burned areas (Keeley and others 2003; Davies and others 2009). It has been shown that B. tectorum distribution depends on climatic variables (Bradley 2009; Bradley and Wilcove 2009) and it follows logically that its response to fire and tendency to form a positive feedback may be associated with climate, though this has yet to be formally tested. Biotic mechanisms are also suggested to be impor- tant, as greater native vegetation cover is associated with lower B. tectorum invasion (Chambers and others 2007; Condon and others 2011). Thus, interactions between climate, native vegetation, and $B$. tectorum may modify the magnitude of $B$. tectorum post-fire abundance and subsequent impact. Understanding the importance and nature of how climate may affect this particularly detrimental invasion is critical as areas that currently do not experience high levels of $B$. tectorum invasion after fire may become more climatically suitable for $B$. tectorum invasion with climate change (Bradley 2009; Bradley and Wilcove 2009). In addition, fire activity in the West is predicted to increase with climate change (Westerling and others 2006). Therefore it is increasingly important to recognize the role that climate plays in the variable response to fire.

Although the differences in response of $B$. tectorum to fire at a local scale have been the focus of most studies (for example, Blank and others 2007; Chambers and others 2007; Shinneman and Baker 2009; Condon and others 2011), the mechanisms that may be driving differences in response to fire at the regional scale have not been addressed. Therefore, the first goal of this study was to determine if climate differences explain the variation seen in $B$. tectorum response to fire at the regional scale. A review of the literature yielded 18 study sites where the response of $B$. tectorum to fire was recorded. We expected that regional temperature and precipitation gradients would be associated with differences in $B$. tectorum response to fire.

The second goal of this study was to determine if a positive feedback between $B$. tectorum and fire existed at a site with little anthropogenic disturbance in southeastern Idaho [Idaho National Laboratory (INL)]. The climate at the INL is intermediate between the areas that do, and do not, experience a positive $B$. tectorum response to fire. The INL provided an ideal location for studying the response of $B$. tectorum to fire because a chronosequence of recent fires created a natural experiment. Recent studies of vegetation at the INL suggest that although $B$. tectorum is present throughout the site, it is not a large component of the overall vegetation (Brummer and others 2013; Lavin and others 2013). However, another recent study of a long-term data set at this site revealed that $B$. tectorum populations increased in the late 1980 s and have remained at moderate densities since then (Bagchi and others 2013). Therefore, the INL represents a site that has been invaded by $B$. tectorum, with an intermediate climate that may or may not be conducive to formation of a positive 
feedback with fire. Thus, we recorded B. tectorum, native perennial grass, and shrub abundance across the chronosequence of fires to determine if fire, independent of physical disturbance, could increase the degree of invasion at this site and facilitate an eventual transition to an annual-dominated state.

\section{MethoDS}

\section{Relationship Between Climate and Regional Patterns of B. tectorum Response to Fire}

To examine our hypothesis that climate patterns may determine $B$. tectorum response to fire at a regional scale, we used empirical studies that examined B. tectorum abundance or biomass before and after a fire, or in paired burned and unburned plots in western USA sagebrush steppe and grass-dominated communities (see Appendix A in Supplementary Material for details). We found a total of 18 study sites, six of which recorded no response (short or long term) of B. tectorum to fire (Antos and others 1983; Humphrey 1984; Cook and others 1994; Seefeldt and McCoy 2003; Menke and Muir 2004; Davies and others 2012b) and 12 of which recorded increases in $B$. tectorum density, seed production, or biomass in burned plots (Pickford 1932; Christensen 1964; Young and Evans 1978; West and Hassan 1985; McArthur and others 1990; Whisenant 1990; Hunter 1991; Billings 1994; Chambers and others 2007; Davies and others 2009; Davies and others 2012a). Nineteen bioclimatic variables, monthly precipitation, monthly minimum temperatures, and monthly maximum temperatures from WorldClim 1.4 data layers (Hijmans and others 2005) were extracted for each study site using the coordinates reported in the respective study (or the best estimates given site descriptions).

We tested if climate variables previously found to be important for describing $B$. tectorum occurrence (Bradley 2009) were different between sites with and without a positive $B$. tectorum response to fire with Welch's two-sample $t$ tests. These climate variables which included summer (June-September) precipitation, average annual precipitation, spring (April and May) precipitation, and winter (December-February) maximum temperature were derived from the monthly precipitation, minimum temperatures, and maximum temperatures extracted from WorldClim.

A principle coordinates (PCO) analysis of the 18 study sites was performed on standardized data that included the 19 bioclimatic variables, monthly precipitation, monthly minimum temperatures, and monthly maximum temperatures, as well as elevation, longitude, and latitude. General linear models were then used to assess the strength and direction of the relationship between PCO axes 1 and 2 and each of the variables used to ordinate the 18 study sites. Individual variables, climate and otherwise, having the strongest relationship with PCO axes 1 and 2 were also evaluated for differences between sites with and without a positive $B$. tectorum response to fire with Welch's $t$ tests. All statistical analyses (including those described below) were performed in the program $\mathrm{R}$ version 2.15.1 (R Development Core Team 2012). The PCO analysis was performed with labdsv (Roberts 2012) and vegan (Oksanen and others 2012).

Finally, we made a predictive map of B. tectorum response to fire under current and future climate scenarios at a regional extent and coarser grain. We used the five bioclimatic variables most correlated with PCO axis 1 (Table 1 ) from the 18 study sites as predictor variables and $B$. tectorum as the response in a logistic regression. Highly collinear variables were eliminated using analysis of variance inflation values (using a VIF $=3$ cutoff value). Corrected Akaike's Information Criterion (AICc) was used to select the best model. The equation from the selected model was then used to create a predictive map displaying the probability of a positive B. tectorum response to fire under current and future climate conditions in the western USA. The current temperature scenario was obtained from the 2.5 min spatial resolution WorldClim data (Hijmans and others 2005). The future climate scenario represents downscaled IPPC $_{5}$ data extracted from the NASA GISS-E2-R general circulation model under the IPPC representative concentration pathway RCP4.5.

\section{Upper Snake River Plain Study Site}

Our site-specific observations were from the INL in southeastern Idaho, USA. The area is approximately $490 \mathrm{~km}^{2}$ with an elevation range from 1,461 to 1,638 $\mathrm{m}$ and dominated by an Artemisia tridentata ssp. wyomingensis (Wyoming big sagebrush) steppe community. The 30-year average summer (July-September) precipitation is $4.3 \mathrm{~cm}$, fall precipitation (October-December) is $5.19 \mathrm{~cm}$, winter precipitation (January-March) is $4.49 \mathrm{~cm}$, and spring precipitation (April-June) is $7.87 \mathrm{~cm}$. Precipitation in the summer, fall, winter, and spring previous to sampling was 2.93, 8.53, 2.96, and $6.49 \mathrm{~cm}$, respectively. The INL site is unique in that it has not been grazed by livestock since the 
Table 1. Results from the General Linear Models Used to Assess the Strength and Direction of the Relationship Between PCO Axis 1 and Each of the Variables Used to Ordinate the 18 Study Sites

\begin{tabular}{|c|c|c|c|c|}
\hline Variable & Coefficient & SE & $P$ value & $R^{2}$ \\
\hline Annual mean temp. & 0.21076 & 0.01549 & $<0.0001$ & 0.91 \\
\hline Precip. of warmest quarter & -0.17011 & 0.02067 & $<0.0001$ & 0.79 \\
\hline Max. temp. warmest month & 0.181 & 0.02391 & $<0.0001$ & 0.76 \\
\hline Mean temp. of coldest quarter & 0.17158 & 0.02377 & $<0.0001$ & 0.74 \\
\hline Mean temp. of warmest quarter & 0.17288 & 0.02412 & $<0.0001$ & 0.74 \\
\hline Precip. of driest month & -0.5914 & 0.09 & $<0.0001$ & 0.7 \\
\hline Precip. of driest quarter & -0.1882 & 0.0292 & $<0.0001$ & 0.69 \\
\hline Min. temp. of coldest month & 0.1399 & 0.0276 & $<0.0001$ & 0.58 \\
\hline Spring precip. (April-June) & -0.1329 & 0.03353 & 0.001 & 0.45 \\
\hline Mean temp. of driest quarter & 0.0405 & 0.0112 & 0.00212 & 0.4 \\
\hline
\end{tabular}

Results for the ten climate variables that were most correlated with PCO 1 are shown in declining order of importance. temp. Temperature, precip. precipitation, min. minimum, max. maximum.

1940s and access to the site is highly restricted, thus disturbance due to human land-use is relatively low. A study of $B$. tectorum occupancy at the site from 2009 through 2011 estimated that the species occupied $82 \%$ of sampled plots (Brummer and others 2013) but with low overall cover (for example, our plot subset had a mean B. tectorum cover of 3.95\%; Anderson and Inouye (2001) found mean B. tectorum cover of $2.28 \%$ in 1995 at the site). Starting in 1994, a series of fires burned roughly half of the previously intact sagebrush communities creating a natural experiment. The ignitions were primarily of human origin. The average fine fuel load in unburned areas, as determined for $64,0.25 \mathrm{~m}^{2}$ random plots using the photoload sampling technique (Keane and Dickinson 2007), was $376.8 \mathrm{~kg} / \mathrm{ha}$ and primarily consisted of standing dead herbaceous cover and small amounts of herbaceous and Artemisia tridentata litter.

\section{Plant Species Abundance Data}

The positive feedback between $B$. tectorum and fire depends on two steps: increased abundance of $B$. tectorum post-fire and increased frequency and size of fires, due largely to increases in fine fuel loads and continuity. B. tectorum cover was recorded in plots across a fire chronosequence to determine if abundance increased post-fire at the INL. Stratified random transects $10 \mathrm{~m}$ wide beginning at random points along roads and continuing for $2 \mathrm{~km}$ perpendicular to the road were delineated (described in more detail in Brummer and others 2013). The transects were stratified by five fire categories: twice burned (10-15 years and 1-year post-fire), 1year post-fire, 3-4 years post-fire, 11-15 years post-fire, and not recorded as burned. Ten $100 \mathrm{~m}^{2}$ plots were selected at random distances along each transect for the purpose of this study. Within each plot the aerial percent cover of B. tectorum, aerial percent cover and identity of the four most dominant vascular plants (excluding B. tectorum), and percent cover of litter were recorded. All cover data were collected by the first author to ensure consistency across plots. Twenty-three transects were sampled for a total of 216 plots. Sampling took place in June 2011.

\section{Data Analysis}

Hurdle models (Carlevaro and others 2012) were used to predict response of three grass types $(B$. tectorum, native bunch grasses, and native rhizomatous grasses) to fire category due to the highly skewed distribution of the native grass cover data. Hurdle models first model the presence and absence of the species using logistic regression and then, where the species is present, model the logarithm of the percent cover of that species. Presence and absence were modeled as a function of time since fire divided into three categories: recently burned (1-year post-fire, 3-4 years post-fire, and burned twice), burned 11-15 years ago, and unburned. Three categories were used instead of all five because some of the smaller categories contained all presence points for each grass group and thus could not be modeled with logistic regression. Both cover and relative cover (percent cover of plant type of interest divided by total plant cover in the plot) were used as response variables to years since fire. Relative cover was analyzed in addition to cover because recently burned areas had lower overall vegetation cover. Therefore, analyzing only cover could miss changes in relative abundance of plant types. The only native rhizomatous grass 
observed was Agropyron dasystachyum. Native bunch grasses were more diverse and included, in decreasing order of frequency: Poa secunda, Elymus elymoides, Agropyron spicatum, Stipa comata, Oryzopsis hymenoides, and Elymus cinereus (taxonomic nomenclature follows Cronquist and others (1977)). Shrub cover and relative cover was log transformed $(+0.1 \%$ was added to all data) and modeled with a linear regression. A hurdle model was not used for shrub cover because all unburned plots contained shrubs and thus a logistic model was not appropriate. Native shrubs observed in decreasing order of frequency included: Chrysothamnus viscidiflorus, A. tridentata, Ericameria nauseosa, Tetradymia canescens, Grayia spinosa, Krascheninnikovia lanata, and Tetradymia spinosa. B. tectorum was present in $93 \%$, native rhizomatous grasses in $33 \%$, native bunch grasses in $73 \%$, and shrubs in $76 \%$ of sampled plots.

To examine whether $B$. tectorum was associated with higher levels of litter cover, and thus contributed to the buildup of fine fuels, litter was modeled as a function of both B. tectorum and native plant cover. Due to the highly skewed distribution, a hurdle model was also used to model percent litter cover as a function of cover of the four vegetation types (B. tectorum, native bunch grasses, native rhizomatous grasses, and shrubs).

Multiple linear regression was used to determine if any correlations existed between $B$. tectorum and native vegetation. $B$. tectorum cover and relative cover (B. tectorum cover divided by total plant cover) were $\log$ transformed $(+0.1 \%$ was added to all data) to achieve normality, and each response variable was analyzed with multiple linear regression with time since fire, aspect, native bunch grass cover, native rhizomatous grass cover and shrub cover as explanatory variables. Aspect was derived in ArcGIS from a $30 \mathrm{~m}$ DEM and was included in the model to account for differences in cover due to topographic position. A semivariogram was constructed for each model to test for residual spatial autocorrelation of the cover data and no significant autocorrelation was evident.

\section{ReSUlTS}

\section{Relationship Between Regional Patterns of $B$. tectorum Response to Fire and Climate}

We found significant differences in climate between study sites in which $B$. tectorum responded positively to fire and those in which it did not (Figures 1, 2). Sites where B. tectorum did not respond to fire had on average $54.1 \mathrm{~mm}$ more summer precipitation (95\% CI 17.4-90.7, $t=3.4, \mathrm{df}=8.7, P=0.009$ ), and mean maximum winter temperatures that were $15.4^{\circ} \mathrm{C}$ colder $(95 \%$ CI -24.6 to $-6.3, t=-3.7$, $\mathrm{df}=11.1, P=0.004)$ than sites with a positive response (Figure 1). There was marginal support for higher spring precipitation in no response sites (95\% CI 1.9-51.3, $t=2.0, \mathrm{df}=13.9, P=0.067$ ) but no significant difference in annual precipitation $(95 \%$ CI -28.6 to $210.9, t=1.7, \mathrm{df}=10.3, P=0.12$ ) between sites (Figure 1). Mean annual temperature, winter maximum temperature, and spring precipitation at the INL suggest that $B$. tectorum is unlikely to respond to fire, whereas the values for annual precipitation, summer precipitation, and mean maximum temperature of the warmest month at the site suggest that $B$. tectorum there could have a positive response to fire (Figure 1).

PCO analysis showed that climate factors did separate sites by $B$. tectorum's response to fire along PCO axis 1 (Figure 2). PCO axis 1 explained 53\% and PCO axis 2 explained $21 \%$ of the variation. Eight climate variables were highly correlated $\left(R^{2}>0.5\right)$ with PCO axis 1 (Table 1). More temperature variables were highly correlated with PCO axis 1 than precipitation variables. The top two variables that were not tested above (mean annual temperature and maximum temperature of warmest month) are different between sites that do and do not have a positive $B$. tectorum response to fire (Mean annual temperature: $95 \%$ CI -5.6 to -2.2 , $t=-5.0, \mathrm{df}=13.3, \quad P=0.0002 ;$ Maximum temperature of warmest month: $95 \% \mathrm{CI}-6.4$ to -2.1 , $t=-4.4, \mathrm{df}=9.8, P=0.001 ;$ Figure 1$)$. The INL fell at an intermediate point along PCO axis 1 between sites that do and do not have a positive $B$. tectorum response to fire (Figure 2).

After identifying the climate variables that differed most between sites with alternative post-fire responses (Table 1) and then eliminating collinear variables, the best logistic model for B. tectorum response to fire included only mean annual temperature (Biol) and precipitation of the warmest quarter (Biol8; Figure 3).

\section{Response to Fire on the Upper Snake River Plain}

\section{B. tectorum Response to Fire}

The incidence and cover of $B$. tectorum did not increase in burned areas of the INL (Figure 4A). The probability of occurrence of $B$. tectorum was not higher in recently burned plots (1-year post-fire, 3-4 years post-fire, and twice burned) than in 

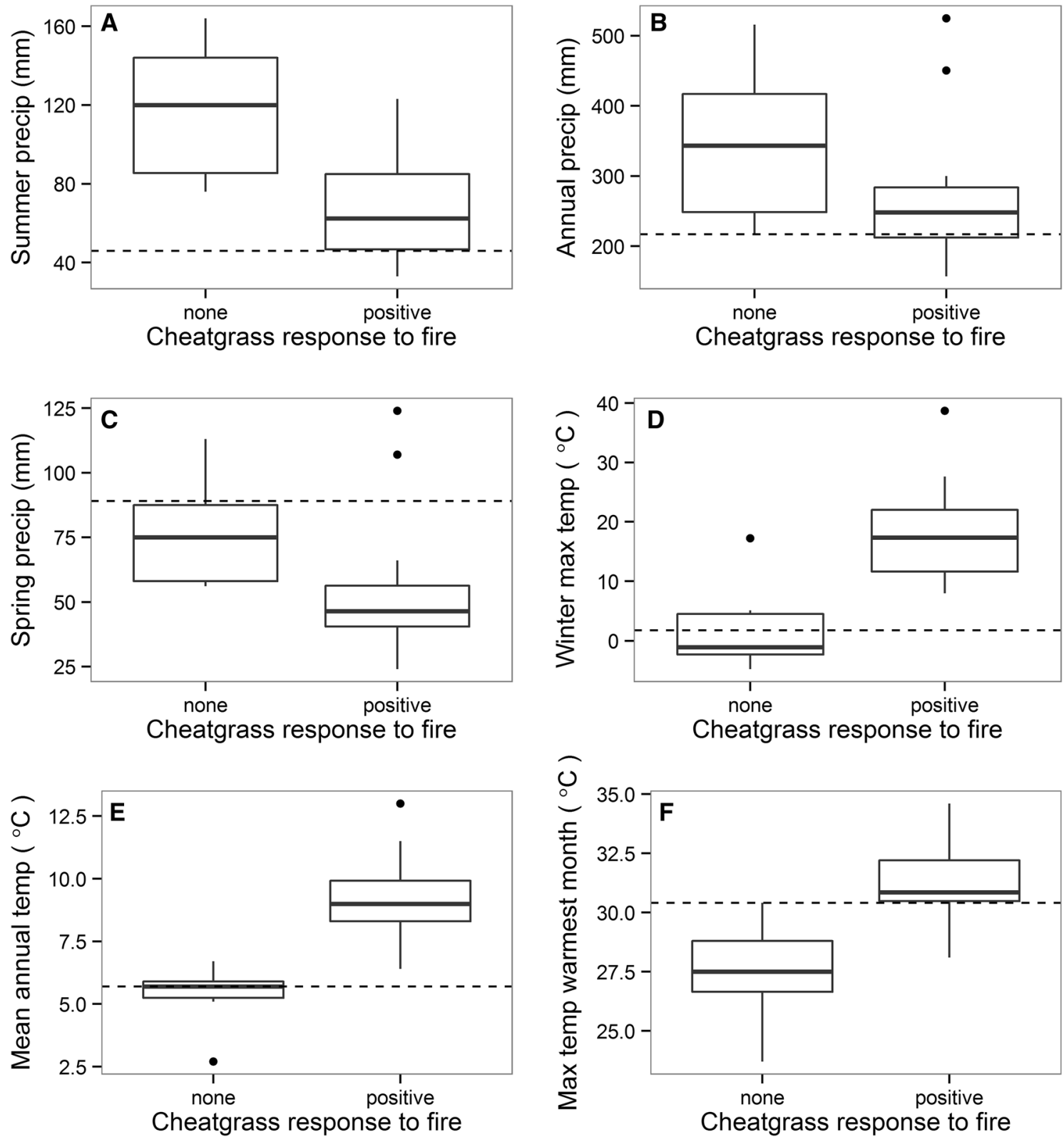

Figure 1. Boxplots showing the climate variables that best explain B. tectorum occurrence (A-D) and other important climate variables for explaining $B$. tectorum response to fire $(\mathbf{E}, \mathbf{F})$ at sites where there is no $B$. tectorum response to fire (none) and sites where there is a positive response to fire (positive). The values for the INL are marked on each plot with a dashed line. Climate variables shown include summer precipitation (precip) (A), annual precipitation (B), spring precipitation $(\mathbf{C})$, winter maximum temperature (temp) (D), annual mean temperature $(\mathbf{E})$, and maximum temperature in the warmest month $(\mathbf{F})$. All temperatures are in degrees Celsius and precipitation is in millimeters. Climate data were extracted from WorldClim 1.4 data layers (Hijmans and others 2005).

unburned plots $(P=0.26$; for detailed statistical results from all hurdle models see Appendix B in Supplementary Material). Indeed, in plots that burned 11-15 years prior to our observations, $B$. tectorum probability of occurrence (probability $=0.70)$ was an estimated $15 \%$ lower than in unburned sites (probability $=0.82, \quad P=0.04$ ) .
When present, cover of $B$. tectorum was not higher in 1 -year post-fire plots $(P=0.44)$, in $11-15$ years post-fire plots $(P=0.89)$ or in the twice burned plots $(P=0.58)$ compared to unburned plots (Figure 4A). In 3-4 years post-fire plots, the median $B$. tectorum cover was one-fifth of the median $B$. tectorum cover in unburned plots $(P=0.002$; 


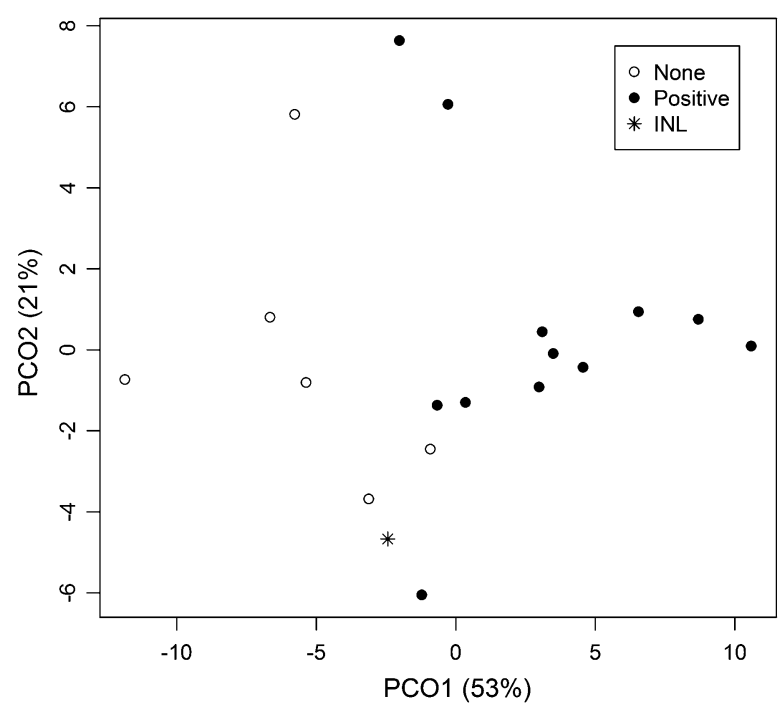

Figure 2. Plot of PCO axes 1 and 2 from the PCO performed on Euclidean distances among the 18 study sites based on climate variables, elevation, longitude and latitude. Filled circles are study sites where there was a positive B. tectorum response to fire and hollow circles are sites where there was no B. tectorum response to fire. The INL site is marked with an asterisk.

Figure 4A). The results for relative cover (B. tectorum cover divided by total plant cover) were similar except that the relative $B$. tectorum cover in plots burned 1 year prior to sampling was higher than in unburned plots $(P=0.009$; Figure $4 \mathrm{~B})$.

Bromus tectorum cover and relative cover were negatively correlated with native bunch grass cover after accounting for time since fire, aspect, shrub cover, and rhizomatous grass cover (cover: $\beta_{\text {bunch }}=$ $-0.12, F_{1,207}=18.36, P<0.0001$; cover model $F_{8,207}=6.14, P<0.0001$, adjusted $R^{2}=0.16$; relative cover: $\beta_{\text {bunch }}=-0.030, F_{1,207}=29.61, P<$ 0.0001 ; relative cover model $F_{8,207}=15.6, P<$ 0.0001 , adjusted $\left.R^{2}=0.35\right)$. B. tectorum cover and relative cover were also negatively correlated with rhizomatous grass cover after accounting for time since fire, aspect, shrub cover, and bunch grass cover $\left(\beta_{\text {rhizom }}=-0.047, \quad F_{1,207}=3.61, \quad P=0.059\right.$ and $\beta_{\text {rhizom }}=-0.037, \quad F_{1,207}=45.18, \quad P<0.0001$, respectively). Finally, $B$. tectorum cover and relative cover were also negatively correlated with shrub cover after accounting for time since fire, aspect, and grass cover $\left(\beta_{\text {shrub }}=-0.060, \quad F_{1,207}=9.58, \quad P=\right.$ 0.002 and $\beta_{\text {shrub }}=-0.073, \quad F_{1,207}=30.48, \quad P<$ 0.0001 , respectively).

\section{Native Bunch Grass Response to Fire}

Native bunch grass cover showed the strongest response to fire between 3 and 15 years after burn- ing. Native bunch grass probability of occurrence in plots burned 11-15 years prior to sampling (probability $=0.88$ ) was an estimated $30 \%$ higher than in unburned plots (probability $=0.62 ; P=0.001$ ) . There was no difference in native bunch grass probability of occurrence between unburned and recently burned plots ( 1 -year post-fire, $P=0.08$; $3-$ 4 years post-fire, $P=0.98$; burned twice, $P=0.52$ ). However, where bunch grasses were present, their median cover was an estimated 4.2 times higher in 3-4 years post-fire plots and 1.7 times higher in $11-$ 15 years post-fire plots than in unburned plots $(P<0.0001 ; \quad P=0.009$, respectively $)$. Where present, bunch grass cover did not differ between unburned plots and plots burned 1 year earlier $(P=0.16)$ or plots burned twice $(P=0.09)$.

Native bunch grasses had higher relative cover in all four time-since-burn categories than in the unburned plots (1 year, $P<0.0001$; 3-4 years, $P<0.0001$; $11-15$ years, $P=0.057$; burned twice, $P<0.0001 ;$ Figure 5A). However, the greatest difference between bunch grass relative cover in unburned and burned plots occurred 3-4 years after fire indicating a potential spike in native perennial bunch grasses 3-4 years post-fire until shrubs begin to dominate again $11-15$ years postfire (Figure 5C).

\section{Native Rhizomatous Grass Response to Fire}

Overall rhizomatous grass (A. dasystachyum) cover and occurrence were higher in recently burned areas (Figure 5B). The probability of occurrence of native rhizomatous grass in recently burned plots (probability $=0.48)$ was an estimated $22 \%$ higher than in unburned plots (probability $=0.37$; $P=0.03$ ) but did not differ between unburned plots and plots burned 11-15 years prior to sampling $(P=0.14)$. No rhizomatous grass was present in the 3-4 years post-fire plots.

Where rhizomatous grass was present, the median cover was an estimated 1.91 times higher in plots burned twice than in unburned plots $(P=0.046$; Figure $5 \mathrm{~B})$, although no difference was detected between unburned plots and plots burned 1 or $11-15$ years before sampling $(P=0.09$ and $P=0.61$, respectively). However, the median relative cover in plots burned both twice and 1 year prior to sampling was more than three times the median relative cover in unburned plots $(P<0.0001$; Figure 5B $)$.

\section{Native Shrub Response to Fire}

Time since fire was a significant predictor of shrub cover $\quad\left(F_{4,211}=67.975, \quad P<0.001, \quad\right.$ adjusted 


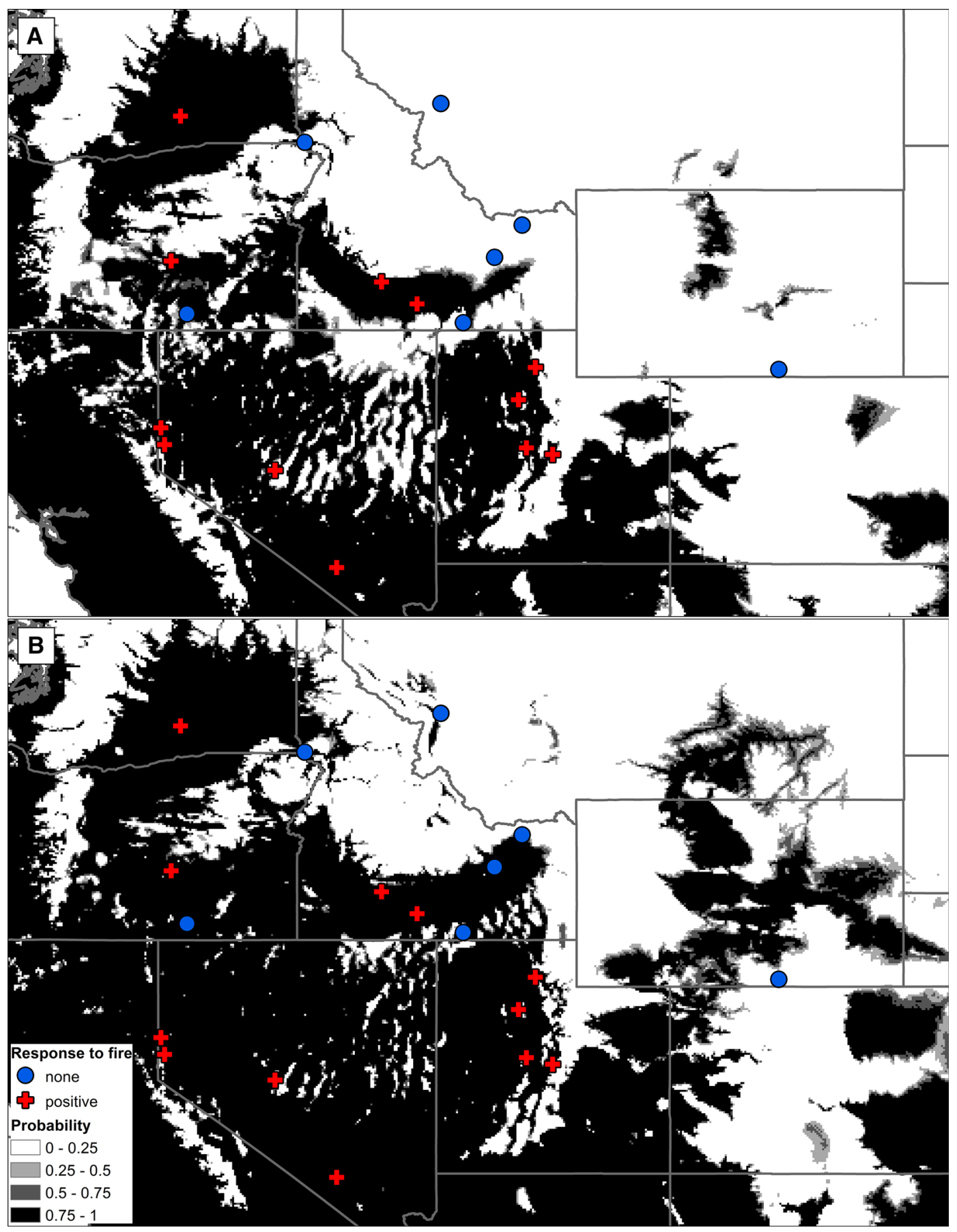

Figure 3. Map of the probability of a positive B. tectorum response to fire across the western USA under current (A) and future (B) climate scenarios. Probabilities are based on the best model (as determined by corrected AIC) of presence and absence of a positive B. tectorum response to fire estimated with logistic regression. The model contained average annual temperature (Biol) and precipitation of the warmest quarter (Biol8) as predictors. The equation for the model of probability of a positive $B$. tectorum response to fire is as follows: Probability $=\exp (-14.41+3.47 \times$ Biol $-0.14 \times$ Biol 18$) /$ $(1+\exp (-14.4+3.47 \times$ Biol $-0.14 \times$ Biol 18$))$ Climate data were obtained from WorldClim at 2.5 minutes spatial resolution (Hijmans and others 2005). The future climate data represent downscaled IPPC $_{5}$ data from the NASA GISS-E2-R general circulation model under the IPPC representative concentration pathway RCP4.5. The blue circles represent study sites where no $B$. tectorum response to fire was observed and the red crosses represent study sites where a positive $B$. tectorum response to fire was recorded. Lowest probabilities are represented with white, graduating through gray to black, the highest probability. 


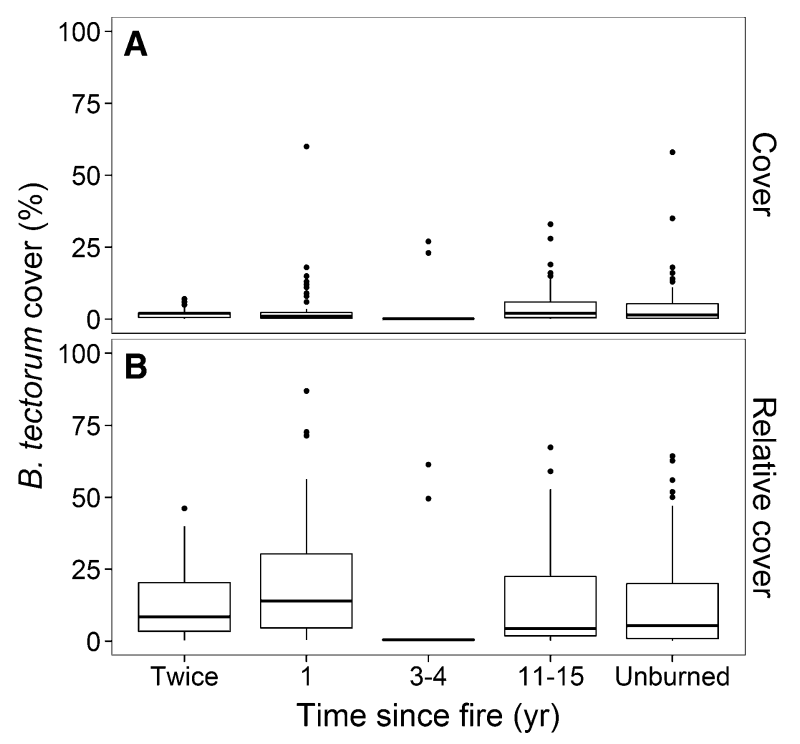

Figure 4. B. tectorum cover $(\mathbf{A})$ and relative cover $(\mathbf{B})$ for each fire category. Cover was estimated in plots where $B$. tectorum was present (that is, no plots scored for zero were included so that the figure matches the results from the second part of the hurdle models). Plots burned twice were burned both 1-year ago and 11-15 years ago.

$\left.R^{2}=0.55\right)$ and relative cover $\left(F_{4,211}=40.82, P<\right.$ 0.001 , adjusted $\left.R^{2}=0.45\right)$. Shrub cover and relative cover were both significantly lower in recently burned than in unburned plots $(P<0.0001$ to $P=0.0064$ for all pairwise comparisons; Figure 5C; Appendix B in Supplementary Material). However, there was no difference in shrub cover or relative cover between plots burned between 11 and 15 years prior to sampling and unburned plots ( $P=0.20$ and $P=0.24$, respectively). In plots burned between 1 and 4 years prior to sampling, the median shrub cover and relative shrub cover were only an estimated $0.5-11 \%$ (for all pairwise comparisons) of the median shrub cover and relative shrub cover in unburned plots. C. viscidiflorus was the most frequent shrub found in recently burned areas due to its ability to resprout post-fire.

\section{Relationship Between Litter and Vegetation Type on the Upper Snake River Plain}

Cover of the different vegetation types was a significant predictor of litter cover $\left(F_{4,211}=25.63\right.$, $P<0.001$, adjusted $\left.R^{2}=0.31\right)$. Litter percent cover was positively correlated with shrub cover $\left(\beta=0.16, F_{1,211}=81.38, P<0.0001\right)$ and bunch grass cover $\left(\beta=0.13, F_{1,211}=17.48, P<0.0001\right)$ after accounting for the other vegetation types. There was no significant relationship between litter

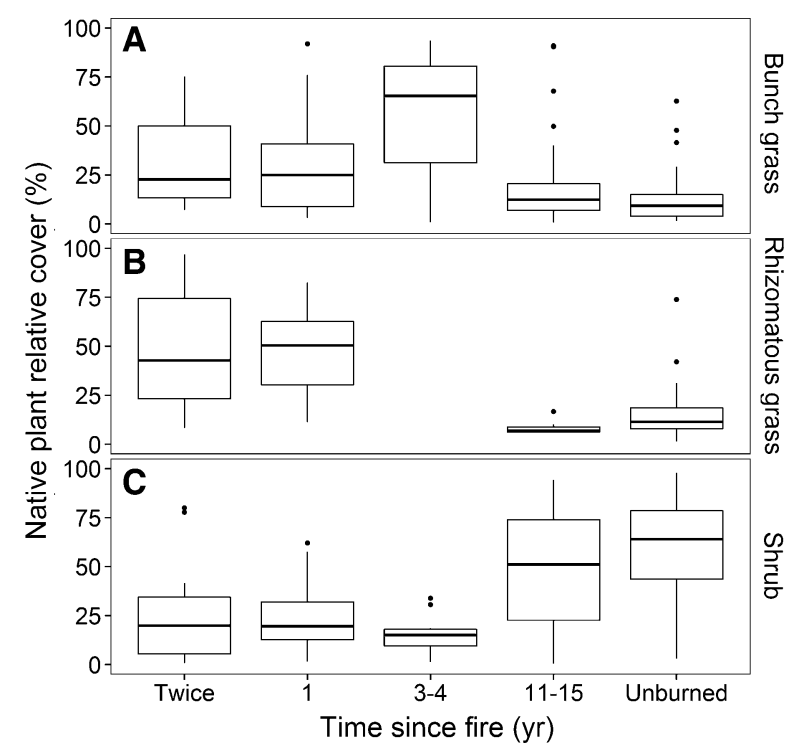

Figure 5. Relative native bunch grass $(\mathbf{A})$, relative native rhizomatous grass $(\mathbf{B})$, and relative shrub $(\mathbf{C})$ cover for each fire category. Cover was estimated in plots where that growth form was present (that is, no plots scored for zero were included so that the figures match the results from the second part of the hurdle models). Plots burned twice were burned both 1 -year ago and $11-$ 15 years ago.

cover and native rhizomatous grass cover $\left(F_{1,211}=\right.$ $0.00, P=0.99)$ or $B$. tectorum cover $\left(F_{1,211}=3.07\right.$, $P=0.08$ ) after accounting for the other vegetation types.

\section{Discussion}

Factors Affecting Regional Differences in the B. tectorum Fire-Feedback

Our first objective was to evaluate if climate was associated with a positive feedback between $B$. tectorum and fire as observed in the sagebrush biome of western USA. We found that climate variables are important predictors of where, geographically, $B$. tectorum may have a positive response to fire and therefore could initiate a positive feedback. This result is not unexpected given that climate has been found to be an important factor in B. tectorum establishment and distribution regionally (Bradford and Lauenroth 2006; Bradley 2009). We found that several of the climatic predictors of $B$. tectorum distribution (Bradley 2009) are also important in predicting its response to fire. However, temperature seems to play a more important role in predicting response to fire than it does in predicting distribution. The winter annual life history strategy 
allows B. tectorum to take advantage of late fall and early spring moisture when other plants (for example, native grasses and forbs) are dormant. $B$. tectorum roots can grow until temperatures drop below $3^{\circ} \mathrm{C}$, whereas the roots of many wheatgrasses cannot grow below $7-8^{\circ} \mathrm{C}$ (Upadhyaya and others 1986). Therefore, the time period over which B. tectorum could be growing, may be longer than for other plants where winter temperatures are warmer.

Precipitation in the summer was found to be important for predicting both $B$. tectorum response to fire (this study) and $B$. tectorum distribution (Bradley 2009). B. tectorum is more successful in areas with lower summer precipitation. Lower summer precipitation could either favor B. tectorum by decreasing the competitiveness of native perennials or by increasing fire frequency (Bradley 2009). Our study suggests that even after fire $B$. tectorum will not increase in abundance in areas with certain climates, potentially because competitiveness of native perennials may be higher than $B$. tectorum in these areas. Higher spring and summer precipitation would negate the benefit of a winter annual life history because water is readily available throughout the growing season, not just in the early spring when $B$. tectorum is photosynthesizing and growing before other species. B. tectorum may be more competitive in areas with less precipitation because its morphology, featuring a highly branched diffuse, shallow root system, takes advantage of small amounts of rain, where more deeply rooted perennial bunchgrasses cannot (Upadhyaya and others 1986). Fire may only accelerate the transition to an annual-dominated state in areas that are climatically favorable to B. tectorum's life history strategy, suggesting that climate rather than fire may be the primary factor mediating $B$. tectorum impact regionally.

In the future, if climate change causes a reduction in spring or summer precipitation and an increase in temperatures, $B$. tectorum could have a positive response to fire in areas of the sagebrush biome where it currently does not respond. Bradley's (2009) bioclimatic envelope model suggested that the border between Idaho and Montana, as well as sections of Wyoming, is most likely to experience increases in $B$. tectorum climate suitability under multiple climate scenarios. If a fundamental shift in climate patterns occurs that asymmetrically favors winter annuals, $B$. tectorum is likely to become more dominant and fire is likely to exacerbate the rate of ecosystem structural and functional changes under new climate conditions (Figure 3).

\section{B. tectorum Response to Fire at a Climatically Intermediate Site}

The second objective of this study was to use a natural fire chronosequence to determine whether fire, in the absence of strong physical disturbance, leads to increased B. tectorum abundance. The results from our climate analysis suggested that the INL was intermediate in climate to areas where $B$. tectorum did and did not increase post-fire. We examined $B$. tectorum cover across a 15 -year postfire chronosequence and found no evidence that $B$. tectorum had increased in response to fire in this native-dominated sagebrush steppe plant community.

Fire in combination with $B$. tectorum is reported to cause an ecosystem transition in some cases (Billings 1994; Mack 2011), an assertion derived from studies in the Great Basin rather than throughout the sagebrush biome. Our results, in the northeast region of the biome, suggest that $B$. tectorum's response to fire can be very ephemeral, and much less pronounced than the response of native perennial bunch and rhizomatous grasses. Native rhizomatous grass exhibited the largest difference in relative abundance between burned and unburned areas 1 year after fire, although bunch grasses also had significantly higher relative abundances in recently burned plots than unburned plots, likely due to the release from competition with shrubs. B. tectorum had the least difference in relative abundance between burned and unburned plots. These results suggest that fire did not cause a transition to an alternate annual-dominated state. Instead, native perennial grasses responded more positively to fire than B. tectorum. Furthermore, increased fire frequency did not necessarily result in $B$. tectorum invasion, as evidenced by the lack of difference in B. tectorum abundance between unburned and twice burned plots.

If a positive feedback between $B$. tectorum and fire was to form, we would expect that $B$. tectorum would produce most of the litter (and thus fine fuel) in an area. However, at the INL there was no significant relationship between $B$. tectorum cover and litter cover, suggesting that B. tectorum was likely not responsible for the majority of the litter at the INL site. In fact, fine fuel loads at the INL were half that of the fuel loads where a positive feedback response of $B$. tectorum to fire was found (Davies and others 2009). Both native shrub and bunch grass cover were significantly positively correlated with litter cover and thus likely more responsible for the buildup of litter fuels than B. tectorum. $B$. tectorum made up only a small percent of the plant 
cover $(3.95$ and $1 \%$ mean and median of abundance plots, respectively) and thus was not present in high enough abundance to have a major impact on fine fuel loads or continuity. These results suggest no positive feedback between fire and $B$. tectorum at the INL.

\section{Factors Driving the Response of $B$. tectorum to Fire Throughout the Sagebrush Biome}

Our climate meta-analysis suggested that climate has a significant effect on $B$. tectorum's response to fire. Other factors that have also been hypothesized to effect B. tectorum's fire response include pre-fire disturbance history and fire severity.

The INL study site has low physical disturbance (for example, grazing, anthropogenic activities) and the site has had approximately 70 years to recover from livestock grazing (Anderson and Inouye 2001; Lavin and others 2013). The sagebrush community is relatively intact and presumably native plant propagules are abundant. In contrast, many sagebrush communities in the Great Basin, including southern Idaho, have a long and continuous history of intense grazing or cropping. We found a negative relationship between native plant cover and B. tectorum cover, suggesting that lower levels of invasion were associated with higher native plant cover. A long-term study at the same site also found a negative correlation between abundance of nonnative species and native plant cover (Anderson and Inouye 2001), which agrees with the finding of a negative relationship of nonnative species diversity and native species diversity in unburned sagebrush steppe of the INL (Lavin and others 2013). Other sites with intact sagebrush, high perennial native cover, or less physical disturbance have also been found to be more resistant to B. tectorum and invasion of exotic species (Daubenmire 1942; Seefeldt and McCoy 2003; Chambers and others 2007; Prevéy and others 2010; Condon and others 2011; Davies and others 2012a).

Although previous disturbances may reduce the resilience of the system to perturbations such as fire, areas that were burned twice (high-frequency disturbance) at the INL site did not show an increase in B. tectorum abundance post-fire. Physical disturbance versus fire can have different effects on plant communities (Lavin and others 2013). However, a stronger positive post-fire response of $B$. tectorum has been found on sites not grazed by domestic livestock than on grazed sites, which was attributed to buildup of fine fuels (Davies and others 2009). Thus, prior physical disturbance, including grazing, is not always the single factor driving post-fire $B$. tectorum invasion, suggesting other interacting factors may be important.

Variability in fire severity between sites may also explain the inconsistent development of a positive $B$. tectorum-fire feedback. More severe fires may result in a more rapid invasion of $B$. tectorum due to increased mortality of native grasses (Davies and others 2009) and may explain the contrasting responses between our results and those of Davies and others (2009) who found a positive response in ungrazed sagebrush steppe. We found no increase in $B$. tectorum relative cover in the twice burned areas relative to unburned areas but did find a slight, transient increase in $B$. tectorum in the more severely burned 1-year post-fire plots, suggesting that fire severity may have an effect. However, that effect was smaller in magnitude and duration (2fold vs 8-fold difference in cover) than that found by Davies and others (2009). This suggests that fires are not as severe in our system or that there is a driver of greater relative importance. The structure of the vegetation at our site was similar to that of Davies and others (2009) and most fires at the INL burned naturally (that is, not prescribed burns on days selected for control of the fires) through dense stands of old-growth $A$. tridentata in mid-summer providing a fuel load and weather conditions that would likely maximize fire severity. Thus our results, compared to those of Davies and others (2009), lead us to believe that factors other than fire severity play a critical role in determining postfire B. tectorum response.

Although prior disturbances and fire severity can explain differences in B. tectorum abundance postfire (Keeley and others 2003; Davies and others $2009,2012 a$ ), our assertion that fire severity and prior disturbance may not always be the most important determinant of post-fire cheatgrass response is supported by other studies in which different sequences and intensities of the same disturbances resulted in drastically different outcomes (see Rew and Johnson 2010 for review). Therefore, we assert that climate has greater relative importance for forecasting whether a positive feedback is observed between B. tectorum and fire at the regional scale. We recognize, however, the local importance of physical disturbance history and fire severity in determining the post-fire $B$. tectorum abundance within sagebrush steppe communities. In addition, interactions between climate, fire, and B. tectorum are likely, given the impact of climate on fire activity in the western USA (Littell and others 2009; Abatzoglou and Kolden 2013). 
Although the climate at the INL is intermediate to climate in areas that do and do not experience increased B. tectorum post-fire, we believe that climate, in combination with other factors, plays a leading role in explaining the lack of a positive $B$. tectorum response to fire at the INL site. Although summer precipitation at the INL is low, spring precipitation is high which may allow native perennial grasses to be more competitive (as suggested by their high post-fire abundances and the negative correlation between them and $B$. tectorum). In addition, winter temperatures at the INL are low, which would limit the advantage $B$. tectorum has as a winter annual. The INL may have the right combination of low disturbance levels and sufficient climate limitations to prevent the formation of a positive feedback between $B$. tectorum and fire. However, it is possible that in other areas that are also climatically intermediate there may be a more positive $B$. tectorum response to fire if disturbance levels are higher.

\section{Conclusions}

The positive feedback between fire and B. tectorum abundance is not consistent across the introduced range of $B$. tectorum in western North America because climate may be interacting with fire to mediate the invasiveness of this winter annual across the sagebrush biome. Although B. tectorum may be an aggressive and transformative invader in the Great Basin and south-central Washington, this response is not universal. Our study suggests that the lack of consistent response and ecosystem impact by $B$. tectorum is associated with differences in climate. In areas of the sagebrush biome that experience cold winters and wet summers, B. tectorum is not likely to develop annual-dominated states, even if fire severity is high. However, it is possible that in such areas local factors such as native plant cover and disturbance level may shift the balance in determining $B$. tectorum response to fire. In the future, climate change could cause $B$. tectorum to become more problematic and form positive feedbacks throughout the northeast part of the sagebrush biome where it historically has not responded positively to fire.

\section{ACKNOWLEDGMENTS}

We would like to thank Gonzales-Stoller Surveillance, LLC and the Idaho National Laboratory (DOE) for access to the site. We would also like to thank Roger Blew, Amy Forman and others at Gonzales-Stoller Surveillance, LLC who helped the project run smoothly. Comments by two anonymous reviewers improved the manuscript. Funding for this project came from Gonzales-Stoller Surveillance (GSS-0300-1100008). KT and BDM were additionally funded by NSF-WildFIRE PIRE, OISE 09667472.

\section{REFERENCES}

Abatzoglou JT, Kolden CA. 2013. Relationships between climate and macroscale area burned in the western United States. Int J Wildland Fire 22:1003-20.

Anderson JE, Inouye RS. 2001. Landscape-scale changes in plant species abundance and biodiversity of a sagebrush steppe over 45 years. Ecol Monogr 71:531-56.

Antos JA, McCune B, Bara C. 1983. The effect of fire on an ungrazed western montana grassland. Am Midl Nat 110:354-64.

Bagchi S, Briske DD, Bestelmeyer BT, Wu XB. 2013. Assessing resilience and state-transition models with historical records of cheatgrass Bromus tectorum invasion in North American sagebrush-steppe. J Appl Ecol 50:1131-41.

Balch JK, Bradley BA, D'Antonio CM, Gomez-Dans J. 2013. Introduced annual grass increases regional fire activity across the arid western USA (1980-2009). Glob Change Biol 19:173-83.

Bangert R, Huntly N. 2010. The distribution of native and exotic plants in a naturally fragmented sagebrush-steppe ecosystem. Biol Invasions 12:1627-40.

Billings WD. 1994. Ecological affects of cheatgrass and resultant fire on ecosystems in the western Great Basin. In: Monsen SB, Kitchen SG, Eds. Ecology and management of annual rangelands. Ogden, UT: USDA Forest Service Intermountain Research Station. p. 22-30.

Blaisdell JP. 1953. Ecological effects of planned burning of sagebrush-grass range on the upper Snake River Plains. Washington, DC: USDA. p 39.

Blank RR, Chambers J, Roundy B, Whittaker A. 2007. Nutrient availability in rangeland soils: influence of prescribed burning, herbaceous vegetation removal, overseeding with Bromus tectorum, season, and elevation. Rangeland Ecol Manag 60: 644-55.

Bradford JB, Lauenroth WK. 2006. Controls over invasion of Bromus tectorum: the importance of climate, soil, disturbance and seed availability. J Veg Sci 17:693-704.

Bradley BA. 2009. Regional analysis of the impacts of climate change on cheatgrass invasion shows potential risk and opportunity. Glob Change Biol 15:196-208.

Bradley BA, Wilcove DS. 2009. When invasive plants disappear: transformative restoration possibilities in the Western United States resulting from climate change. Restor Ecol 17:715-21.

Brooks ML, D'Antonio CM, Richardson DM, Grace JB, Keeley JE, DiTomaso JM, Hobbs RJ, Pellant M, Pyke D. 2004. Effects of invasive alien plants on fire regimes. BioScience 54:677-88.

Brummer TJ, Maxwell BD, Higgs MD, Rew LJ. 2013. Implementing and interpreting local-scale invasive species distribution models. Divers Distrib 19:919-32.

Carlevaro F, Croissant Y, Hoareau S. 2012. mhurdle: estimation of models with limited dependent variables. $\mathrm{R}$ package version 0.1-3.

Chambers JC, Roundy BA, Blank RR, Meyer SE, Whittaker A. 2007. What makes Great Basin sagebrush ecosystems invasible by Bromus tectorum? Ecol Monogr 77:117-45. 
Christensen EM. 1964. Changes in composition of a Bromus tectorum-Sporobolus cryptandrus-Aristida longiseta community following fire. Proc Utah Acad Sci Arts Lett 41:53-7.

Condon L, Weisberg PJ, Chambers JC. 2011 . Abiotic and biotic influences on Bromus tectorum invasion and Artemisia tridentata recovery after fire. Int J Wildland Fire 20:597-604.

Cook JG, Hershey TJ, Irwin LL. 1994. Vegetative response to burning on Wyoming mountain-shrub big game ranges. J Range Manag 47:296-302.

Cronquist A, Holmgren AH, Holmgren NH, Reveal JL, Holmgren PK. 1977. Intermountain Flora. Bronx, NY: New York Botanical Garden Press.

D'Antonio CM, Vitousek PM. 1992. Biological invasions by exotic grasses, the grass/fire cycle, and global change. Ann Rev Ecol Syst 23:63-87.

Daubenmire RF. 1942. An ecological study of the vegetation of Southeastern Washington and Adjacent Idaho. Ecol Monogr 12:53-79.

Davies GM, Bakker JD, Dettweiler-Robinson E, Dunwiddie PW, Hall SA, Downs J, Evans J. 2012a. Trajectories of change in sagebrush steppe vegetation communities in relation to multiple wildfires. Ecol Appl 22:1562-77.

Davies KW, Bates JD, Nafus AM. 2012b. Comparing burned and mowed treatments in Mountain Big Sagebrush Steppe. Environ Manag 50:451-61.

Davies KW, Svejcar TJ, Bates JD. 2009. Interaction of historical and nonhistorical disturbances maintains native plant communities. Ecol Appl 19:1536-45.

Hijmans RJ, Cameron SE, Parra JL, Jones PG, Jarvis A. 2005. Very high resolution interpolated climate surfaces for global land areas. Int J Climatol 25:1965-78.

Hosten PE, West NE. 1994. Cheatgrass dynamics following wildfire on a sagebrush semidesert site in central Utah. In: Monsen SB, Ketchum SG, Eds. Ecology and management of annual rangelands. Boise, ID: USDA Forest Service. p. 56-62.

Humphrey LD. 1984. Patterns and mechanisms of plant succession after fire on Artemisia-grass sites in Southeastern Idaho. Vegetatio 57:91-101.

Hunter R. 1991. Bromus invasions on the Nevada Test Site: present status of B. rubens and B. tectorum with notes on their relationship to disturbance and altitude. Great Basin Nat 51:176-82.

Keane RE, Dickinson LJ. 2007. The photoload sampling technique. Fort Collins, CO: USDA Forest Service Rocky Mountain Research Station. p 44.

Keeley JE, Lubin D, Fotheringham CJ. 2003. Fire and grazing impacts on plant diversity and alien plant invasions in the southern Sierra Nevada. Ecol Appl 13:1355-74.

Lavin M, Brummer TJ, Quire R, Maxwell BD, Rew LJ. 2013. Physical disturbance shapes vascular plant diversity more profoundly than fire in the sagebrush steppe of southeastern Idaho, USA. Ecol Evol 3:1626-41.

Levine JM, Vila M, D'Antonio CM, Dukes JS, Grigulis K, Lavorel S. 2003. Mechanisms underlying the impacts of exotic plant invasions. Proc R Soc B Biol Sci 270:775-81.

Link SO, Keeler CW, Hill RW, Hagen E. 2006. Bromus tectorum cover mapping and fire risk. Int J Wildland Fire 15:113-19.

Littell JS, McKenzie D, Peterson DL, Westerling AL. 2009. Climate and wildfire area burned in western U.S. ecoprovinces, 1916-2003. Ecol Appl 19:1003-21.

Mack RN. 2011. Fifty years of "waging war on cheatgrass": research advances, while meaningful control languishes. In:
Richardson DM, Ed. Fifty years of invasion ecology. Oxford: Wiley. p. 253-65.

Mata-Gonzalez R, Hunter RG, Coldren CL, McLendon T, Paschke MW. 2007. Modelling plant growth dynamics in sagebrush steppe communities affected by fire. J Arid Environ 69:144-57.

McArthur ED, Blauer AC, Stevens R. 1990. Forage kochia competition with cheatgrass in central Utah. In: McArthur ED, Romney EM, Smith SD, Tueller PT, Eds. Symposium on cheatgrass invasion, shrub die-off, and other aspects of shrub biology and management. Las Vegas, NV: USDA Forest Service, Intermountain Research Station, Ogden, UT. p. 56-65.

Menke CA, Muir PS. 2004. Short-term influence of wildfire on canyon grassland plant communities and Spalding's catchfly, a threatened plant. Northwest Sci 78:192-203.

Oksanen J, Guillaume Blanchet F, Kindt R, Legendre P, Minchin PR, O'Hara RG, Simpson GL, Solymos P, Stevens MHH, Wagner H. 2012. Vegan: community ecology package. R package version 2.0-4. http://CRAN.R-project.org/package= vegan.

Pellant M. 1990. The cheatgrass-wildfire cylce: are there any solutions? In: McArthur ED, Romney EM, Smith SD, Tueller PT, Eds. Symposium on cheatgrass invasion, shrub die-off, and other aspects of shrub biology and management. Las Vegas, NV: USDA Forest Service. p. 11-8.

Pickford GD. 1932. The influence of continued heavy grazing and of promiscuous burning on spring-fall ranges in Utah. Ecology 13:159-71.

Prevéy JS, Germino MJ, Huntly NJ, Inouye RS. 2010. Exotic plants increase and native plants decrease with loss of foundation species in sagebrush steppe. Plant Ecol 207:39-49.

R Development Core Team. 2012. R: a language and environment for statistical computing. R Foundation for Statistical Computing, Geneva.

Rew LJ, Johnson MP. 2010. Reviewing the role of wildfire on the occurrence and spread of invasive plant species in wild land areas of the Intermountain Western United States. Invasive Plant Sci Manag 3:347-64.

Roberts DW 2012. labdsv: ordination and multivariate analysis for ecology. R package version 1.5-0. http://cran.rproject.org/ package=labdsv.

Seefeldt SS, McCoy SD. 2003. Measuring plant diversity in the tall threetip sagebrush steppe: influence of previous grazing management practices. Environ Manag 32:234-45.

Shinneman DJ, Baker WL. 2009. Environmental and climatic variables as potential drivers of post-fire cover of cheatgrass (Bromus tectorum) in seeded and unseeded semiarid ecosystems. Int J Wildland Fire 18:191-202.

Upadhyaya MK, Turkington R, McIlvride D. 1986. The biology of Canadian weeds. 75. Bromus tectorum L. Can J Plant Sci 66:689-709.

West NE, Hassan MA. 1985. Recovery of sagebrush-grass vegetation following wildfire. J Range Manag 38:131-4.

West NE, Yorks TP. 2002. Vegetation responses following wildfire on grazed and ungrazed sagebrush semi-desert. J Range Manag 55:171-81.

Westerling AL, Hidalgo HG, Cayan DR, Swetnam TW. 2006. Warming and earlier spring increase western US forest wildfire activity. Science 313:940-3.

Whisenant SG. 1990. Changing fire frequencies on Idaho's Snake River Plains: ecological and management implications. In: McArthur ED, Romney EM, Smith SD, Tueller PT, Eds. 
Symposium on cheatgrass invasion, shrub die-off, and other aspects of shrub biology and management. Las Vegas, NV: USDA Forest Service. p. 4-10.

Young JA, Evans RA. 1973. Downey brome-intruder in the plant succession of big sagebrush communities in the Great Basin. $J$ Range Manag 26:410-15.
Young JA, Evans RA. 1978. Population dynamics after wildfires in sagebrush grasslands. J Range Manag 31:283-9. 